tomakh (2010). [New philosophical encyclopedia]. Moscow, No. 4, 737 p. [in Russian].

7. Oleksyuk, O. (2013). Muzychna pedahohika [Music pedagogy]. Kyiv, 248 p. [in Ukrainian].

8. Padalka, G. (2008). Pedahohika mystetstva: teoriya i metodyka vykladannya mystetskykh dystsyplin [Pedagogy of art: theory and methods of teaching art disciplines]. Kyiv, 274 p. [in Ukrainian].

9. Pigrov, K. (2001). Khorovaya kultura y moe uchastye $\mathrm{v}$ ney [Choral culture and my participation in it]. Odessa, 50 p. [in Russian].

10. Rudnytska, O. (2002). Pedahohika: zahalna ta mystetska [Pedagogy: general and artistic]. Kyiv, 270 p. [in Ukrainian].

11. Tkachova, N. (2006). Aksiolohichnyy pidkhid do orhanizatsiyi pedahohichnoho protsesu v zahalnoosvitnomu navchalnomu zakladi [Axiological approach to the organization of the pedagogical process in the secondary school]. Luhansk: Taras Shevchenko National Pedagogical University, 300 p. [in Ukrainian].

12. Fedyura, S. (2013). Khorove vykonavstvo na suchasnomu etapi [Choral performance at the present stage]. Scientific notes of Mykola Gogol Nizhyn State University. Psychological and pedagogical sciences, Issue 1, pp. 71-74. [in Ukrainian].

Стаття надійшла до редакції 26.05.2020

УДК 78.087.68:37(377)1094

DOI:

Анатолій Мартинюк, кандидат мистеиттвознавства, дочент кафедри мистеиьких дисииплін і методик навчання ДВНЗ "Університет Григорія Сковороди в Переяславі"

\title{
ПРОФЕСІЙНА МАЙСТЕРНІСТЬ ЗАСНОВНИКА УКРАЇНСЬКОГО НАРОДНОГО ХОРОВОГО СПІВУ ГРИГОРІЯ ВЕРЬОВКИ
}

У статті висвітлено професійну майстерність засновника украйнського народного хорового співу Григорія Верьовки. Визначено, що професійна майстерність засновника українського хорового співу Г.Г. Верьовки передбачає начіональні пісенні традиџї і забезпечує сприйнятливість цих традиџій в сучасному соиіокультурному середовищі. Доведено, щзо митечь пропагував аксіологічний підхід до виховання і навчання молодого покоління. Окреслюються основні педагогічні умови у навчальному прочесі осягнення студентами національної пісенно-хорової спадщини.

Ключові слова: хоровий диригент; професійна майстерність; український народний хоровий спів; Г.Г. Верьовка.

Jim. 10.

Anatoliy Martynyuk, Ph.D. (Art Studies), Associate Professor of the Art Disciplines and Teaching Methods Department Hryhoriy Skovoroda University in Pereyaslav

\section{PROFESSIONAL SKILL OF THE FOUNDER OF UKRAINIAN FOLK CHORAL SINGING HRYHORIY VERYOVKA}

In the article the professional skills of the founder of Ukrainian folk choral singing Hryhoriy Veryovka are highlighted. It is determined that the professional skill of the founder of Ukrainian choral singing H. Veryovka takes into account the national song traditions and ensures the receptivity of these traditions in the modern socio-cultural environment, applying them to the actual process of preserving and increasing national spirituality. It is proved that the artist promoted an axiological approach to the upbringing and education of the younger generation, saw the purpose and content of education in ensuring of the connection between Ukrainian folk songs and choral compositions of foreign classics, recognition of the process of personality formation in Ukrainian choral traditions. It is actualized the statement that the uniqueness of $H$. Veryovka's professional skill in all its dimensions - performing-conducting, composer, pedagogical, educational, organizational - lies in the development of his special choral intonation, palette of sound tones, sound production in organic integrity, which takes place at the fundamental level of the national song and choral tradition and European principles of collective singing. The main pedagogical conditions in the educational process of the students' comprehension of the national song and choral heritage are outlined.

Thus, analyzing the professional skill of the founder of Ukrainian folk choral singing $H$. Veryovka, we can conclude that the features of his vocal pedagogy played an important role in the national choral school. The scientific study of $H$. Veryovka's musical and pedagogical experience became the basis of the national and world conducting and choral pedagogy, formation of the highly moral personality capable of multiplying the achievements of Ukrainian folk singing.

Keywords: choral conductor; a professional skill; Ukrainian folk choral singing; H. Veryovka.

П остановка проблеми. У сучасному суспільстві проблема виховання всебічно розвиненої особистості,

збереження національних традицій підкреслюе велике значення українського народного хорового мистецтва, яке є органічною складовою 
національної культури, що базується на етнічній специфіці. Сьогодні зростаючому поколінню слід не тільки розвиватися розумово, але й оволодівати цілісною національною культурою, духовністю та багатогранним надбанням нашого народу, зокрема, українським народним хоровим співом [1]. Отже, у наш час великого значення набуває вивчення мистецького та педагогічного досвіду видатних постатей.

Серед уславленого сузір'я діячів національної музичної культури ХХ ст. вирізняється непересічна постать Г.Г. Верьовки. Його надзвичайно плідна мистецька діяльність як композитора, хорового диригента і педагога стала важливим джерелом формування київської диригентсько-хорової школи. Отже, метою статті дослідити професійну майстерність засновника українського народного хорового співу Г.Г. Верьовки та проаналізувати його міркування стосовно зв'язку і взаємозалежності культури і освіти.

Аналіз останніх досліджень і публікацій. Постать Г.Г. Верьовки як фундатора українського хорового мистецтва розглядали видатні музикознавці, диригенти, педагоги. Аспекти музично-виконавської діяльності аналізуються у дослідженняхО.Бенч-Шокало,А.Гуменюк,В.Дженкова, Л. Пархоменко, В. Перепелюк, С. Козак, М. Кречко та ін. Слід зауважити, що багато наукових праць, присвячених диригенту Г.Г. Верьовці характеризують професійну виконавську діяльність видатного митця українського хорового мистецтва, але проаналізувавши науковометодичну літературу з досліджуваної проблеми з'ясували, що реалії сьогодення потребують грунтовного розгляду професійної майстерності засновника українського хорового мистецтва Г.Г. Верьовки з урахуванням сучасних досягнень педагогічної науки.

Отже, метою статті $\epsilon$ висвітлення професійної майстерності засновника українського народного хорового співу Григорія Верьовки.

Виклад основного матеріалу. Україна $\epsilon$ важливим центром народного хорового мистецтва. Невичерпність та краса українського народного хорового співу завжди заворожувала й надихала до творчості педагогів, композиторів, диригентів хорового мистецтва. 3 цього приводу Г.Г. Верьовка зазначав: “Тільки віднайдене в скарбниці народної творчості й відгранене талантом справжнього художника - безсмертне” [2].

В музично-драматичному інституті імені М.В. Лисенка, де Григорій Верьовка здобув грунтовну музичну освіту, відзначається надзвичайно тонкий музичний слух видатного митця, його виняткове вміння читати нотний текст 3 аркушу, а також особлива здатність стисло і точно розкривати змістовну наповненість певного музичного поняття або явища $[3,114]$.

Особливу цінність у роки навчання Г. Верьовки в музично-драматичномуінститугіімені М.В. Лисенка містять спогади професора Маргарити Людвіг, які $\epsilon$ надзвичайно змістовними і набувають значення важливого джерела для осмислення феномену цієї непересічної особистості. Наголошується на тому, що це була людина надзвичайної цілеспрямованості, працелюбності і старанності. Основним вектором його навчальних студій було вивчення мистецтва композиції і диригування. Він сумлінно опановував гру на фортепіано і скрипці, а також поглиблював свої знання в галузі філософії, літератури, образотворчого мистецтва і німецької мови. Григорія Верьовку вирізняло прагнення до досконалості у різних сферах. Про це свідчать маловідомі сторінки його біографії, насамперед багатолітня співпраця з оркестром Київського оперного театру, де він виконував партію другої скрипки. В домашньому музикуванні він брав участь у складі струнного квартету [5].

У роки навчання в музично-драматичному інституті імені М.В. Лисенка яскраво розкривається обдарування Григорія Верьовки як хорового диригента. Мистецтво композиції він опановував в класі Б.Л. Яворського, - фундатора і керівника Народної консерваторії. Невід’ ємним елементом системи освітнього процесу була практична діяльність студентів зміст якого на початковому етапі охоплював два основні аспекти: розучування зі слухачами хорових партій та допомога їм у засвоєнні музично-теоретичних знань і сольфеджіо. Про його винятковий диригентський хист засвідчила надзвичайно плідна діяльність $з$ хором Народної консерваторії. Ïї перебіг засвідчує винятковий вплив музичнопросвітницьких ідей Б.Л. Яворського. В його наукових розвідках наголошується на винятковому культуротворчому впливі хорового мистецтва для духовного розвитку українського суспільства, а також формування високих естетичних i морально-етичних цінностей та ідеалів особистості. Погляди Б.Л. Яворського, які віддзеркалюють національні культурні традиції і найбільш важливі глибинні риси української ментальності, про виняткову суспільну значущість та виховну місію хорового співу помітно вплинули на розвиток художнього світогляду Григорія Верьовки та його подальшу музично-виконавську і педагогічну діяльність на теренах хорового мистецтва. Так, педагогічні погляди Г. Верьовки 


\section{ПРОФЕСІЙНА МАЙСТЕРНІСТЬ ЗАСНОВНИКА УКРӒ̈НСЬКОГОНАРОДНОГО ХОРОВОГОСПІВУ}

ГРИГОРІЯ ВЕРЬОВКИ

віддзеркалюють окремі положення музичнотеоретичної концепції визначного вченого і музиканта Б.Л. Яворського, який був фундатором новаторської теорії ладового ритму. Дослідник О. Немкович відзначає, що "Ії ядром було функціональне розуміння сутності ладу в нерозривній взаємопов'язаності двох начал стійкого і нестійкого. А розгортання зазначеного співвідношення в часі утворювало ладовий ритм" $[8,187]$. Ладовий аспект музичного твору розглядався у взаємодії з іншими елементами музичної композиції. Важливим пріоритетом наукової діяльності вченого було вивчення питань музичної форми. “Виділення Б. Яворським поняття музичної інтонації, осмислення музики як виразної людської мови перебувало в річищі досліджень загальноєвропейського музикознавства, загалом гуманітарної думки" [8, 189]. Тобто, ідеї вченого виявляють певні змістові паралелі 3 поглядами Б. Асаф'єва на музичну форму й музичний твір. Відзначимо, що науковопедагогічний доробок Б.Л. Яворського був у витоків сучасної системи музичної освіти, яка зберігає свою цінність до нашого часу.

Композиторська і хорова школа Григорія Верьовки віддзеркалює його грунтовну вокальну підготовку. Мистецтво сольного співу він опановував в класі Н.А. Калнинь-Гондольфі, згодом брав консультації у автора спогадів. Він добре оволодів голосом, про що свідчить майстерне виконання ним низки романсів М. Глинки, А. Рубінштейна, П. Чайковського, Р. Шумана, М. Лисенка, Я. Степового, а також більш складних музичних композицій вокально-хорової та оперної класики. Отже, отриманий музичновиконавський досвід в роки навчання поглибив розуміння композитором жанрової своєрідності вокальної музики.

Педагогічна діяльність Григорія Верьовки та Елеонори Скрипчинської у Київській консерваторії значною мірою визначила позитивну динаміку розвитку української диригентсько-хорової школи. Особистості цих визначних музикантів і педагогів необхідно розглядати, на наш погляд, в нерозривній єдності. Художня естетика та педагогічні погляди Г.Г. Верьовки та Е.П. Скрипчинської сприяли формуванню гуманітарного світогляду та неповторної мистецької індивідуальності М. Кречка, П. Муравського та Л. Венедиктова [7]. Подвижницька праця цих видатних диригентів значною мірою визначили основні вектори розвитку національної хорової школи як академічний хоровий спів; хорове виконавство, яке має своїм підгрунтям автентичні співацькі традиції; хоровий спів як невід'ємний елемент мистецької освіти; хоровий спів в контексті музично-театральної культури.

Уже в перші десятиліття своєї диригентської діяльності Г. Верьовка уособлює найбільш динамічний ступінь розвитку українського хорового мистецтва. Ним було започатковано винятково демократичні форми впровадження мистецтва хорового співу в маси. Подальша його творча праця позначена втіленням в життя ідеї щодо зростання художнього рівня хорового виконання. Вона увінчалася створенням еталонного Українського народного хору, що ознаменувало виникнення нового виконавського напряму. Професор А. Лащенко висловлює думку про те, що цей виконавський напрямок сприяв самозбереженню й самовдосконаленню хорового мистецтва в складних суспільних реаліях того часу $[6,44]$.

Професійна майстерність диригента, цілісність художньої натури Г. Верьовки, його особливе, народне ліричне обдарування помітно вплинули на формування виконавського стилю Українського народного хору. Схиляємось до думки дослідника О. Скопцової: “. . . спиирання на традиції народного гуртового співу та носіїв цієї традиції, відчуття імпровізаційної природи українського народного мелосу, культивування багатоголосного розпіву, збагачення хорового співу стильовими засобами музично-інструментального та хореографічного мистецтв, застосування елементів театралізації, сценографії, усвідомлення хору як художньої цілісності” $[9,135]$.

Неповторними звуковими барвами вирізнялася інтерпретація протяжних ліричних пісень, передусім таких перлин українського народу як “Понад садом, садом”, “Ой при лужку, там плавали сірі гуси у кружку”, “Ой не пугай, пугач, пугаченьку”, або виконання жартівливих - “Жито мати, жито мити”, “Пожену я сиві воли до води”. Відомий хоровий диригент і педагог Анатолій Захаров висловлює думку про те, що “Тут маємо рідкісне майстерне володіння усіма таємницями народно-пісенної традиції - бездоганний стрій, досконалий ансамбль і надзвичайної краси м'який, сріблястий чарівний звук. Як природно, як переконливо, як схвильовано, артистично звучали кожна пісня, кожне слово поетичного тексту!" [3, 144]. Як зазначається далі, вражала легкість, витонченість, якась природна грація диригентської манери Григорія Верьовки. Видатному диригентові були притаманні точний і вольовий жест, а також виняткова гострота слуху. Сучасників вражало надзвичайне вміння диригента відтворювати складний ритмічний малюнок, передусім в багатьох протяжних піснях 

ГРИГОРІЯ ВЕРЬОВКИ

3 підголосками. Диригентський стиль Григорія Верьовки позначений глибиною осягнення i відтворення художньої концепції творів, надзвичайним даром донести свої ідеї до артистів колективу та скерувати на створення яскравої і всеохоплюючої виконавської інтерпретації.

Диригентській педагогіці Григорія Верьовки притаманні такі основні риси: надзвичайна прозорливість і точність у визначенні своєрідності диригентського обдарування студентів; створення умов для самостійного розв'язання студентом низки навчальних завдань; лаконічний виклад навчального матеріалу, ясне відтворення диригентських жестів; тісний взаємозв'язок диригентсько-технічного твору з глибоким вивченням образної сфери та музичної стилістики [4, $27-29]$.

Навчальний процес 3 дисципліни “Хорове диригування" віддзеркалювали грунтовну музично-теоретичну підготовку і багатолітній практичний досвід Г. Верьовки. Диригентську педагогіку видатного музиканта вирізняв особливий підхід щодо виявлення творчої ініціативи студента, розкриття глибинної художньої сутності твору, пошуки таких засобів диригентського втілення, за яких художня інтерпретація твору була б найбільш переконливою. 3 цього приводу, колишній випускник Київської консерваторії Микола Білан в спогадах про свого викладача 3 дисципліни “Хорове диригування” Г.Г. Верьовку, розкриває важливі риси художньої естетики та музичної педагогіки видатного диригента [3]. В спогадах відтворено маловідомі сторінки культурномистецького життя Івано-Франківщини, зокрема відзначається широкий суспільний резонанс, який мали концертні виступи Українського народного хору під керуванням Григорія Верьовки. Чудові музиканти іпедагоги Г. Верьовка таЕ. Скрипчинська сприяли поширенню культуротворчих обріїв студента, поглибили його обізнаність в галузі національної та світової хорової класики. У ці роки визначилися основні пріоритети подальшої творчої діяльності Миколи Білана, серед яких виконавська інтерпретація та художнє опрацювання української народної пісні [10].

Культурний універсалізм постаті Г.Г. Верьовки став підгрунтям для поширення меж навчальної діяльності в галузі диригентсько-хорової педагогіки. Його багатолітня праця в царині музичної фольклористики отримала віддзеркалення в змісті освітнього процесу. Важливим спрямуванням видатного хорового диригента було осягнення студентами національної пісеннохорової спадщини. В освітньому процесі реалізовувалися так, в якому можна окреслити педагогічні умови:

1. Поглиблення світоглядних уявлень студентів щодо сутності музичного фольклору та особливостей його функціонування в духовному житті українського суспільства.

2. Особистісне ставлення до національного пісенно-хорового стилю як цілісного художнього явища та виявлення його етнорегіональних відмінностей.

3. Висвітлення основних методологічних принципів щодо художнього опрацювання автентичної музичної спадщини.

4. Поширення меж навчальної діяльності студентів, створення ними обробок українських народних пісень, започаткування традиції виконання цих творів хором консерваторії під час проведення державних іспитів.

5. Виконавське втілення музичних творів в студентському хорі та всебічне осмислення художньої естетики та творчого методу визначних диригентів.

6. Художня інтерпретація хорових творів в диригентському класі.

Професійна майстерність засновника українського народного хорового мистецтва Григорія Верьовки є яскравим прикладом гуманістичної, культуровідповідної педагогіки, яка інтегрує в собі соціокультурні, філософські, психологічні, освітньо-виховні та інші аспекти, які безумовно, відображені в спогадах видатних письменників, поетів. Так, в спогадах видатного поета П. Тичини розкривається феномен особистості Г. Верьовки. “Треба ще додати до цього і свого серце - серце людини. Отаке ж якраз прекрасне й чудодійне серце творця і було у Григорія Верьовки" $[3,15]$. Йому були притаманні винятково тонкий слух до переймання народної пісні; уміння навчати народної пісні інших. Видатний письменник М. Стельмах відзначав глибинну сутність життєвого покликання Г. Верьовки, а саме: "Він був народжений для музики, він був зітканий із музики, з отих народних чарів, що веселять, чи смутком лягають на душу, чи підносять її угору на добрих крилах надії, сподівань" $[3,20]$, тобто, українські народні пісні в художньому опрацюванні композитора та звучанні його хору постійно озивалися в душі письменника.

У своїх працях Г.Г. Верьовка трактує обробки народних пісень як сукупність цінностей, вірувань, стосунків між людьми, норм поведінки, етикету, характерних для українського народу. Вказуючи на вирішальний вплив народно-хорового співу на особистість, педагог окреслив українські народні пісні одними з фундаментальних чинників освіти 
й виховання молоді. 3 урахуванням зазначеного, видатний хоровий диригент і педагог визначив одним із основних підходів у навчальному процесі з дисципліни “Хоровий клас” саме аксіологічний, суттю якого вважав передачу загальнолюдських цінностей вихованцю через народно-хоровий спів досвід, традиції українського народу.

Висновки і перспективи подальших наукових розвідок. Мистецький досвід засновника українського народного хорового співу Г.Г. Верьовки передбачає величезну цінність вітчизняної і зарубіжної культури. Сутність його освітньої концепції полягає в її культурологічній та аксіологічної спрямованості. Митець пропагував аксіологічний підхід до виховання, визнання процесу становлення особистості на українських хорових традиціях, вбачав мету і зміст освіти й виховання в забезпеченні зв'язку між української народної піснею та хоровими творами зарубіжної класики. Будучи засновником українського народного хорового співу, Г. Верьовка певною мірою випередив свій час, його професійна майстерність щодо навчання і виховання молодого покоління, формування високоморальної особистості, здатної примножувати надбання і здобутки українського народного співу, має прогностичний характер й співзвучні сучасним тенденціям освіти і виховання.

\section{ЛІТЕРАТУРА}

1. Бенч-Шокало О. Український хоровий спів. Актуалізація звичаєвої традиції. Київ, 2002. 440 с.

2. Верьовка Г. Берегти народні пісенні багатства. Науково-популярний журнал з питань музичної культури. Київ, 1995. № 6. С. 14-15.

3. Верьовка Г. Спогади. Київ, 1972. 220 с.

4. Дженков В. Дивосвіт Григорія Верьовки. 1986. № 6. С. 27-29.

5. Козак С. Григорій Верьовка: біограф. повість. Київ, 1981. 232 с.

6. Лащенко А. 3 історії київської хорової школи. Київ, 2007. 200 с.

7. Національній музичній академії України імені П.І. Чайковського 100 років. Київ, 2013. 512 с.

8. Немкович О. Українське музикознавство XX століття як система наукових дисциплін. Київ, 2006. $534 \mathrm{c}$.
9. Скопцова О. Становлення та особливості розвитку народного хорового виконавства в Україні (кінець XIX - початок XX ст.). Київ, 2017. $180 \mathrm{c}$.

10. Ященко Л. Григорій Гурійович Верьовка: нариси про життя і творчість. Київ, 1963. 63 с.

\section{REFERENCES}

1. Bench-Shokalo, O. (2002). Ukrayinskyy khorovyy spiv. Aktualizatsiya zvychayevoyi tradytsiyi [Ukrainian choral singing. Actualization of customary tradition]. Kyiv, 440 p. [in Ukrainian].

2. Veryovka, G. (1995). Berehty narodni pisenni bahatstva [Preserve folk song riches]. Popular science magazine on music culture. Kyiv, No. 6, pp. 14-15. [in Ukrainian].

3. Veryovka, G. (1972). Spohady [Memories]. Kyiv, 220 p. [in Ukrainian].

4. Dzhenkov, V. (1986). Dyvosvit Hryhoriya Verovky [The Miracle of Gregory Veryovka]. No. 6, pp. 27-29. [in Ukrainian].

5. Kozak, S. (1981). Hryhoriy Verovka: biohraf. povist. [Hryhoriy Veryovka: biographer. story]. Kyiv, 232 p. [in Ukrainian].

6. Lashchenko, A. (2007). Z istoriyi kyyivskoyi khorovoyi shkoly [From the history of the Kyiv choral school]. Kyiv, 200 p. [in Ukrainian].

7. Natsionalniy muzychniy akademiyi Ukrayiny imeni P.I. Chaykovskoho 100 rokiv [National Music Academy of Ukraine named after P.I. Tchaikovsky 100 years]. Kyiv, 2013. 512 p. [in Ukrainian].

8. Nemkovych, O. (2006). Ukrayinske muzykoznavstvo XX stolittya yak systema naukovykh dystsyplin. [Ukrainian musicology of the twentieth century as a system of scientific disciplines]. Kyiv, 534 p. [in Ukrainian].

9. Skoptsova, O. (2017). Stanovlennya ta osoblyvosti rozvytku narodnoho khorovoho vykonavstva $v$ Ukrayini (kinets XIX - pochatok $X X$ st.). [Formation and features of development of folk choral performance in Ukraine (late XIX - early XX century)]. Kyiv, 180 p. [in Ukrainian].

10. Yashchenko, L. (1963). Hryhoriy Huriyovych Verovka: narysy pro zhyttya i tvorchist [Grigory Gurievich Veryovka: essays on life and work]. Kyiv, 63 p. [in Ukrainian].

Стаття надійшла до редакції 10.06.2020

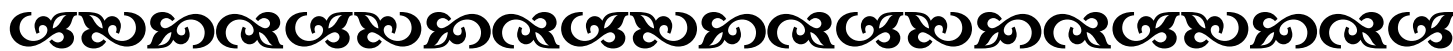

“В багатство, фбізина досконалість”.

Василь Сухомлинський украӥнсъкий педагог

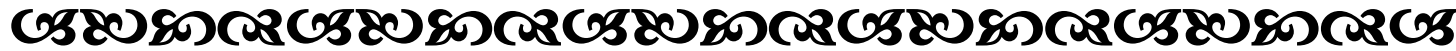

